\title{
Effect of Mangiferin on muscle GLUT4 protein content in TSOD (Tsumura, Suzuki, Obese, Diabetes) mouse, a new type 2 diabetic mice
}

\author{
Toshihiro Miura ${ }^{* 1}$, Naoki Iwamoto', Motoshi Kato', Hiroyuki IchikI ${ }^{2}$, Masayoshi Kubo', \\ Yasuhiro Komatsu ${ }^{2}$, Hiroshi SaSAKI ${ }^{2}$, Torao IshIDA ${ }^{3}$ and Keiichiro TANIGAwa ${ }^{1}$ \\ ' Department of Clinical Nutrition, Suzuka University of Medical Science, 1001-1 Kishioka, Suzuka, Mie 510-0293, Japan. ${ }^{2}$ Tsumura \\ Central Research Laboratories, Tsumura and Co., 3586 Yoshiwara, Ami-machi, Inashiki-gun, Ibaraki 300-11, Japan. ${ }^{3}$ Hi-tech Research \\ Center, Suzuka University of Medical Science, 1001-1 Kishioka-cho, Suzuka, Mie, 510-0293, Japan.
}

(Received 19 October. 2001; and Accepted 1 November 2001)

\begin{abstract}
The effect of Mangiferin (MF) on muscle GLUT4 protein content was studied in TSOD (Tsumura, Suzuki, Obese, Diabetes) mice, a new animal model of type 2 diabetes with hyperinsulinemia. MF reduced the blood glucose of TSOD mice $7 \mathrm{~h}$ after oral administration, and also significantly lowered the serum insulin of TSOD mice under similar conditions. The muscle content of facilitative glucose transporter isoform 4 (GLUT4) protein content in the plasma membrane fraction of muscle significantly increased in the orally MF-treated mice when compared with that in the controls. These results suggest that the antidiabetic effect of MF is derived, at least in part, from the increase of GLUT4 protein content in the plasma membrane of the muscle.
\end{abstract}

Insulin resistance in peripheral tissues, together with the impairment of glucose-induced insulin secretion from pancreatic beta cells, is known as one of the major pathogenic factors of type 2 diabetes. Therapeutic agents to stimulate insulin secretion (for example, sulfonylureas) have been used for type 2 diabetic patients, whereas a limited number of drugs is available to decrease insulin resistance (13)

The rhizoma of Anemarrhena asphodeloides has been used in oriental as traditional medicine for diabetes (polyuria and polydipsia) (23) and conteined xanthone compound, Mangiferin (MF) (14). Ichiki et al. reported that MF-treatment reduced the blood glucose of KK-Ay mice (8). It is reported that MF with exercise decreased the blood glucose (9) and lipid (15) of KK-Ay mice. However, detailed antidiabetic mechanism, remains still unclear.

The Tsumura Suzuki Obese Diabetes (TSOD) mouse train, a new genetic type 2 diabetes model, develops moderate degrees of obesity and diabetes that are especially apparent in animals of more than

Corresponding to: Dr Toshihiro Miura at above address. Fax: +81-593-83-9666, E-mail: miura@suzuka-u.ac.jp
11 week old. Phenotypic characterization revealed that the TSOD mouse had reduced insulin sensitivity (24). Through a whole genome scan of quantitative trait loci (QTLs) affecting body weight, blood glucose, and insulin levels, Hirayama et. al. (7) have identified three major loci meeting the rigorous criteria for linkage.

Glucose transport across the plasma membrane is mediated by carrier proteins termed glucose transporters $(20,25)$. Recent cDNA cloning has demonstrated that the facilitative glucose transporters comprise a family of structurally related proteins with differing tissue distribution (3). The gene expression and protein content of glucose transporters have been found to be altered under pathological conditions such as diabetes mellitus $(3,4,21)$.

In the present study, we have examined the effect of MF on blood glucose, and we also investigated the protein content of the muscle glucose transporter isoform 4 (GLUT4) in order to elucidate the mechanism of the antidiabetic effect using TSOD mouse.

Materials. MF was isolated by conventional method as previously reported (6). The structure of MF was 
confirmed by spectroscopic method (6). This was stored at room temperature until use.

Animals. TSOD mice (Tsumura, Ibaraki, Japan), 22 weeks old, were used. TSOD mice with blood glucose level above $300 \mathrm{mg} / 100 \mathrm{~mL}$ were considered to be diabetic in this study. The mice were housed in an air-conditioned room at $22 \pm 2{ }^{\circ} \mathrm{C}$ with a $12 \mathrm{~h}$ light-12 $\mathrm{h}$ dark cycle (light: 9:00 am to 9:00). The animals were kept in the experimental animal room for 7 days with free access to food (CE-2, Clea, Tokyo, Japan) and water (tap water). Blood samples were drawn from the cavernous sinus with a capillary to determine blood glucose levels under non-anesthesia and non-fasting. MF was dissolved in distilled water. The studies were started at 10:0011:00 am. The oral administration of MF were given on a compulsory basis.

Determination of Blood Glucose and Insulin. Blood glucose levels in mice were determined by the glucose oxidase method (22), and serum insulin was measured by the double antibody method (1).

Isolation of Hindlimb Muscle. The mice were given insulin $(0.5 \mathrm{U} / \mathrm{kg})$ subcutaneously and, $0.5 \mathrm{~h}$ later, the hindlimb muscle was resected for the experiment.

Plasma Membrane (PM) Fraction of Skeletal Muscle. The muscle tissue was placed in a buffer $(5 \mathrm{mM}$ sodium azide, $0.25 \mathrm{M}$ sucrose, $0.1 \mathrm{mM}$ phenylmethylsulfonyl fluoride (PMSF), $10 \mathrm{mM} \mathrm{NaHCO} 3(\mathrm{pH}$ 7.0)) at $4^{\circ} \mathrm{C}$. Subfractionation of muscle membrane was as described by Baron et al (2) whose procedure was modified from that of Klip et al $(11,12)$. The muscle was homogenized and was centrifuged at $1,000 \mathrm{~g}$ for $10 \mathrm{~min}$, and the supernatant was saved. The resulting pellet was resuspended in the buffer and rehomogenized with a glass homogenization tube. The supernatant was combined with the first supernatant, and centrifuged at $9,000 \mathrm{~g}$ for 10 min. The resulting supernatant was then centrifuged at $190,000 \mathrm{~g}$ for $60 \mathrm{~min}$. These membranes were applied to a discontinuous sucrose gradient containing $25 \%, 30 \%$, and $35 \%$ sucrose (wt/vol) solutions and was centrifuged at $190,000 \mathrm{~g}$ for $16 \mathrm{~h}$. Plasma membranes were collected in $25 \%$ sucrose gradients, resuspended in the buffer, pelleted by centrifugation at $190,000 \mathrm{~g}$ for $60 \mathrm{~min}$, and resuspended in the buffer.

Western Blot Analysis. The antibody used in the Western blotting (East Acres, USA) was raised against a synthetic peptide corresponding to the
COOH-terminal domain of mouse GLUT4 (12 amino acid peptide), as reported by James et al. (10) (No reaction against brain, or liver. Does not crossreact with GLUT1 or GLUT2 tested). To prepare the total membrane particulate fractions, the mice muscle were excised and 1-2 g of muscle slice was homogenized in $25 \mathrm{~mL}$ of $10 \mathrm{mM}$ Tris- $\mathrm{HCl}, 1 \mathrm{mM}$ phenylmethyl sulphonyl fluoride and 1000 units $/ \mathrm{mL}$ of aprotinin (18). The homogenates were then centrifuged at $700 \mathrm{~g}$ for $10 \mathrm{~min}$ at $4{ }^{\circ} \mathrm{C}$ to sediment the fraction containing mainly the nuclei and mitochondria. The resulting supernatant was centrifuged at $13,000 \mathrm{~g}$ for $20 \mathrm{~min}$ at $4{ }^{\circ} \mathrm{C}$ to yield a pellet designated as the membrane fraction of the muscle in this study. The membrane fractions $(30 \mu \mathrm{g})$ prepared were suspended in $1 \%$ SDS and $50 \mathrm{mM}$ dithiothreitol and subjected to SDS-polyacrylamide (9\%) gel electrophoresis. Electrophoretic transfer to nitrocellulose paper and detection of the immunocomplex with enhanced chemiluminescence (Amersham, Buckinghamshire, UK) were carried out as has been previously described (19). The sheet was exposed on RX X-ray film and intensifying screen (Fuji, Tokyo, Japan). The prestained molecular weight standard (Bio-Rad, Richmond, VA, USA) was used for estimation of the molecular weight. The experiments were performed at least twice for each tissue with similar results.

Statistical Analysis. All the data were expressed as mean \pm SEM, and Student's t-test was used for the statistical analysis. The values were considered to be significant when the $P$ value was less than 0.05 .

The effect of MF on Blood Glucose in TSOD, The effect of MF injected p.o. to TSOD mice is shown in Table 1. MF-treated animals $(100 \mathrm{mg} / \mathrm{kg}$ body weight) showed lower blood glucose levels from $7 \mathrm{~h}$ after the administration $(P<0.01)$. The serum insulin level in MF-treated mice decreased $7 \mathrm{~h}$ after the administration $(P<0.01)$ (Table 1$)$.

\section{Muscle GLUT4 Protein}

Effects of MF on GLUT4 protein levels in both control and MF-treated TSOD mice are demonstrated in Fig. 1. The quantitation of GLUT4 protein in membrane in muscle was assessed by Western blotting in the mice. Quantitation of the GLUT4 glucose transporter band isolated from nitrocellulose paper demonstrated that relative amount of GLUT4 protein in the muscle from MF treated mice was $164 \%$ of that observed in the control mice $(P<0.01)$ (Fig. 1).

This study clearly showed that the water extract 
Table 1 Effect of MF on blood glucose and insulin in TSOD mice

\begin{tabular}{ccc}
\hline & $\begin{array}{c}\text { Blood glucose }(\mathrm{mg} / \mathrm{dL}) \\
(7 \mathrm{~h})\end{array}$ & $\begin{array}{c}\text { Insulin }(\mu \mathrm{U} / \mathrm{mL}) \\
(7 \mathrm{~h})\end{array}$ \\
\hline Control & $522 \pm 31$ & $178 \pm 4$ \\
\hline MF & $359 \pm 30^{*}$ & $122 \pm 4^{*}$ \\
\hline
\end{tabular}

Each value represents the mean \pm SEM from 5 mice.

Significanlty different from control, ${ }^{*} P<0.01$.

Control MF
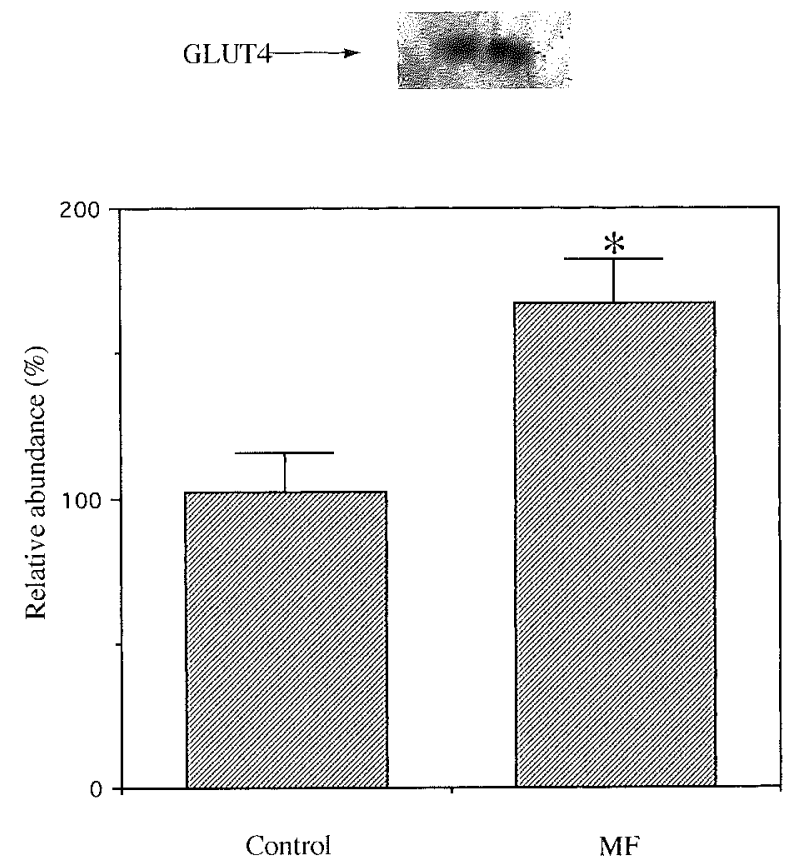

Fig. 1 Effect of MF on GLUT4 Content in Mouse Skeletal Muscle Each value represents the mean \pm SEM of 5 mice Significantly different from control, ${ }^{*} P<0.01$

of the fruits of Mangiferin produces a consistent hypoglycemic effect. In the preliminary study, we examined the dose-dependence $(4,20,100 \mathrm{mg} / \mathrm{kg}$ body weight) $7 \mathrm{~h}$ after the single administration of $\mathrm{MF}$, and found that the most effective dose was 100 $\mathrm{mg} / \mathrm{kg}$. It seems likely that MF display hypoglycemic activity after metabolic process, because MF lowered blood glucose $7 \mathrm{~h}$ after the administration. We examined the therapeutic effects of MF on hyperglycemia in TSOD mice, an animal model with type 2 diabetes mellitus. TSOD mice, which are known for genetically induced diabetes, including ob/ob mice (5) and KK mice (16), were hyperinsulinemia as a result of insulin resistance (17). After treatment with MF, hypoglycemia resulted with reduced serum insulin. These results indicate that MF improves hyperinsulinemia in type 2 diabetes. The insulin resistance in peripheral tissues is known to be one of the major pathogenic factors of type 2 diabetes. The finding that MF decreases blood insulin level in TSOD mice, is important.

In addition, we examined the effect of MF on GLUT4 glucose transporter in mouse muscle, since it has been reproted that GLUT4 plays a crucial role in the muscle process of glucose uptake. MF increased GLUT4 protein content of muscle in TSOD mice. It is known that GLUT4 and GLUT1 are present in skeletal muscle. However, MF did not affect GLUT1 protein content in skeletal muscle (data not shown). From these findings, it is likely that the hypoglycemic effect of MF is derived, at least in part, from the decrease in insulin resistance, due presumably to the increase of GLUT4 protein content in total membrane of muscle.

Further study would show how MF could become a useful drug in the treatment of diabetes through this unique therapeutic mechanism. The present results may give a therapeutic basis for the antidiabetic activity of MF on type 2 diabetes.

\section{REFERENCES}

1. Bailei C. J., Ahmed-Sorour H. (1980) Role of ovarian hormones in the long-term control of glucose homeostasis. Diabetologia 19: 475-481.

2. Baron A., Zhu J. S., Zhu J. H., Weldon H., Maianu L., Garvey M. T. (1995) Glucosamine induces insulin resistance in vivo by affecting GLUT4 translocation in skeletal muscle. Implications for glucose toxicity. J. Clin. Invest. 97: 2792-2801.

3. Bell G. I., Kayano T., Buse J. B., Burant C. F., Takeda J., Lin D., Fukumoto H., Seino S. (1990) Molecular biology of mammalian glucose transporters. Diabetes Care 13: 198-208.

4. Berger J., Biswas C., Vicario P. P., Strout H. V., Seperstein R., Pilch P. F. (1989) Decreased expression of the insulin-responsive glucose transporter in diabetes and fasting. Nature 340: $70^{-72 .}$

5. Coleman D. L. (1982) Diabetes-obesity syndromes in mice. Diabetes 31 (Suppl. 1): 1-6.

6. Fujita M., Inoue T. (1982) Studies on the constituents of Iris 
florentina L. C-glucosides Xanthones and Flavones from the leaves. Chem. Pharm. Bull, 30, 2342-2348.

7. Hirayama I., Yi Z., Izumi S., Arai I., Suzuki W., Nagamachi Y., Kuwano H., Takeuchi T., Izumi T. (1999) Genetic analysis of obese diabetesin the TSOD mouse. Diabetes 48,1183 1191.

8. Ichiki H., Miura T., Kubo M., Ishihara E., Komatsu Y., Okada M., Tanigawa K. (1998) New antidiabetic compounds, mangiferin and its glucoside. Biol. Pharm. Bull., 21, 13891390.

9. Iwamoto N., Miura T., Kato M., Takemoto T., Ichiki H., Kubo M., Komatsu Y., Ishihara E., Sasaki H., Ishida T., Seino Y., Tanigawa K. (2000) Effect of mangiferin with exercise in early stage symptom of type 2 diabetic mice. Biomed. Res., 21, 221-223.

10. James D. E., Strube M., Mueckler M. (1989) Molecular cloning and characterization of an insulin-regulatable glucose transporter. Nature 338: 83-87.

11. Klip A., Ramlal T., Young D. A., Holloszy J. O. (1987) Insulin-stimulated glucose transporters in rat hindlimb muscles. FEBS Lett. 224: 224-230.

12. Klip A., Ramlal T., Bilan P. J., Cartee G. D., Gulve E. A., Holloszy J. O. (1990) Recruitment of GLUT4 glucose transporter by insulin in diabetic rat skeletal muscle. Biochem. Biophys. Res. Commum. 172: 728-736.

13. Masuda K., Okamoto Y., Tsuura Y., Kato S., Miura T., Tsuda K., Hosikoshi H., Ishida H., Seino Y. (1995) Effect of Troglitazone (CS-045) on insulin secretion in isolated rat pancreatic islet and HIT cells: an insulinotropic mechanism distinct from glibenclamide. Diabetologia, 38, 34-30.

14. Miura T., Ichiki H., Hashimoto I., Iwamoto N., Kato M., Kubo M., Ishihara E., Komatsu Y., Okada M., Ishida T., Tanigawa K. (2001) Antidiabetic activity of a xanthone compound, mangiferin. Phytomedicine, 8, 85-87.
15. Miura T., Fukuta C., Ichiki H., Iwamoto N., Kato M., Kubo M., Komatsu Y., Ishida T., Okada M., Tanigawa K. (2001) Hypolipidemic activity of mangiferin in cholesterol-fed mice. J. Trad. Medcines, 18, 119-121.

16. Nakamura M. (1962) A diabetic strain of the mouse. Proc. Jpn. Acad. 38: 348-352.

17. Nishimura M. (1969) Breeding of mice strains for diabetes mellitus. Exp. Animal 18: 147-157.

18. Oka Y., Asano T., Shibasaki A. (1990) Increased liver glucose transporter protein and mRNA in streptozotocin-induced diabetic mice. Diabetes 39: 441-446.

5) Coleman D. L. (1982) Diabetes-obesity syndromes in mice. Diabetes 31 (Suppl. 1): 1-6.

19. Perez C., Albert I., DeFay K. (1990) A nonsecretable cell surface mutant of tumor necrosis factor (TNF) kills by cell-tocell contact. Cell 63: 251-258.

20. Simpson I. A., Cushman S. W. (1986) Hormonal regulation of mammalian glucose transport. Ann. Rev. Biochem. 55: 1059-1089.

21. Sivitz W. I., Desautel S. L., Kayano T., Bell G. I., Pessin J. E. (1989) Regulation of glucose transporter messenger RNA in insulin-deficient states. Nature 340: 72-74.

22. Stevens J. F. (1951) Determination of blood glucose by glucose oxidase method. Clin. Chim. Acta. 32: 199-201.

23. Suzuki J., and Kimura M (1993) Hypoglycemic effect of the blended Chinese traditional medicines in genetically and chemically diabetic mice. Folia Pharmacol. Japon, 83, 1-10.

24. Suzuki W., Iizuka S., Tabuchi M., Funo S., Yanagisawa T., Kimura M., Sato T., Endo T., Kawamura H. (1999) A new mouse model of spontaneous diabetes derived from $\mathrm{ddY}$ strain. Exp. Anim., 48, 181-189.

25. Wheeler T. J., Hinkle P. C. (1985) The glucose transporter of mammalian cells. Ann. Rev. Physiol. 47: 503-517. 